\title{
REASSESSING JUSTIN MARTYR'S BINITARIAN ORIENTATION IN 1 APOLOGY 33
}

\author{
STEPHEN O. PRESLEY*
}

Southwestern Baptist Theological Seminary

\begin{abstract}
Many scholars argue that Justin is either inconsistent or confused in his view of the Spirit in relation to the Logos. The most decisive section in this discussion is 1Apol. 33, where Justin appears to confuse the titles and unify the functions of the Logos and the Spirit. This essay argues that this apparent confusion is conditioned by Justin's particular christological reading of Isaiah 7:14 in order to meet the demands of his own understanding of the apostolic faith. The interpretation of Isaiah 7:14 is a unique case with multiple external hermeneutical pressures imposing upon his exegesis, including those coming from competing Jewish exegesis, Greco-Roman mythology, and Marcionite interpretations. At the same time, Justin reads scripture within his own Christian community. Justin's exegesis of Isaiah 7:14 attempts to account for these external pressures by focusing upon the particular Lukan terminology of 'Power' rather than 'Spirit' in Luke 1:35, which downplays the function of the Spirit in the incarnation in order to demonstrate that the Logos has come in power. This exegetical move exposes him to binitarian allegations, but does not suggest that Justin is, in fact, a binitarian. What this suggests, however, is that in $1 \mathrm{Apol}$. 33 Justin actually resists confusing the Logos and the Spirit even when a text uses the language of 'Spirit', because his exegetical concern is focused on the Logos coming in power. Justin's exegetical treatment of Isaiah 7:14 and Luke 1:35 reflects the way he is reasoning through the textual and theological complexities of the christological interpretation of scripture and does not suggest that he confuses the functions of the Logos and the Spirit.
\end{abstract}

KEYWORDS: christology, Logos theology, hermeneutics, biblical interpretation, Isaiah 7:14

\section{Introduction}

Amongst studies on Justin's doctrine of God, it is commonplace to argue that he is either inconsistent or confused in his assessment of the relationship of the Spirit and the Logos (Goodenough 1968: 102ff; Osborn 1973: 88-89; Stanton 2004: 321ff; Vigne 2000: 335ff.). The position that Justin has no real doctrine of the Spirit and therefore no serious trinitarian theology can be traced back to Goodenough, who, among others, defends this conclusion from Justin's regular enigmatic use of the various divine titles relat- 
ed to the Logos and the Spirit. In recent years, however, several scholars have addressed this thorny problem through analyzing the way Justin's socalled Spirit christology accounts for his apparent binitarian logic (Bucar 2008: 190-208; Briggman 2009: 107-137; Barnes 2001). The most recent and thorough treatment is Anthony Briggman's essay, which concludes that 'in Justin's thought binitarian logic exists in tension alongside trinitarian belief, a combination that obscures the activity and identity of the Spirit' (Briggman 2009: 108).

Justin has, as Briggman points out, 'clear statements of Trinitarian belief' with various triadic formulas that coexist alongside Justin's 'regular failure to differentiate' the activity of the Son and the Spirit and the 'occasional failure' to differentiate their identity (Briggman 2009: 110). Briggman's analysis holds in tension both sides of the argument with a solution that is highly plausible, but not entirely satisfying. He still paints a portrait of a confused, doubleminded Justin that gathers on Sunday with others to confess a trinitarian baptismal creed (1Apol. 67), but then sets aside this confession and becomes binitarian when he debates or defends the faith. In my view, however, another way forward is a greater appreciation for Justin's hermeneutical perspective and the way he navigates the particular terms and concepts of scripture passages within his particular apologetic and polemical contexts. As Behr observes, 'little effort has been given to integrate Justin's "Logos Theology" with the position found in his Dialogue with Trypho the Jew, where he devotes himself almost exclusively to scriptural interpretation' (Behr 2001: 107). Studies on Justin often present him as 'two people': the theological Justin of the Apologies and the exegetical Justin of the Dialogue, so perhaps a closer reading of Justin's exegetical orientation could help clarify some aspects of his theological framework and especially the relationship between his pneumatology and Logos theology (Edwards 1995: 261).

The place to begin assessing the relationship of the Logos and the Spirit in Justin's work is 1Apol. 33. This is the focal point of Justin's apparent confusion of the Logos and the Spirit and the proof-text par excellence. Without exception, scholars who argue that Justin confuses the Logos and the Spirit point to this chapter and the peculiar phrase: 'It is established that the Spirit and the Power are to be understood as none other than the Logos' (Goodenough 1968: 177-178; Barnard 1967: 103-4; Osborn 1973: 88-9; Bucur 2008: 194-96; Briggman 2009: 119-121). Even Edwin Goodenough observes that this 'is the only passage where the Logos is called a Spirit' (Goodenough 1968: 235, n. 5). In the words of Stanton, 'Justin's lack of precision concerning the role of the Spirit is nowhere clearer than in 1Apology 33' (Stanton 2004: 331). It is also worth noting that all other arguments on Justin's confusion of the Logos and the Spirit are based upon the confusion 
of their functions not their titles (1Apol. 33.9, 36, 38). 1Apol. 33 is the only instance where Justin appears to confuse their titles and unifies their functions. However, from his hermeneutical perspective, what makes the issue of Justin's apparent confusion of the Logos and the Spirit in 1Apol. 33 even more perplexing is that Justin cites Lukan and Matthean testimonia that include the language of 'Holy Spirit'. The apparent confusion, therefore, is not merely a matter of elucidating Justin's own theological perspective, but explaining how Justin could insist upon his conclusions while citing what appear to be New Testament passages mentioning the work of the Spirit. In other words, why would Justin so explicitly betray, in the words of Stanton, 'the family likeness of his "grandfather" Luke' (Stanton 2004: 332)?

As we consider 1Apol. 33, it is important to observe that Justin's theological and exegetical attention is not given to Luke or Matthew per se, but Isaiah. The prophecy of the virgin birth in Isaiah 7:14 orients the entire section. In his exegesis of Isaiah 7:14, Justin borrows Lukan vocabulary derived from Luke 1:35 and combines this with the citation of an early Christian fulfillment report that conflates Luke 1:31-32/Matthew 1:20-21. So although Justin retains Lukan vocabulary in his exegesis, his purpose in this section, along with most of the sections spanning 1Apol. 31.7-1Apol. 53, is the demonstration of Christ from the Old Testament. Justin is concerned with the christological, not necessarily pneumatological, interpretation of the Old Testament. It is noteworthy, however, that the prophecy was given through the Spirit; thus, in Justin's logic the Spirit inspires the prophets, while the Son fulfills what is proclaimed (1Apol. 33.1).

In this paper, therefore, I will argue that the identification of the Logos with the Spirit in 1Apol. 33 is conditioned by Justin's particular christological reading of Isaiah 7:14 in order to meet the demands of his exegetical and theological situation. I will first demonstrate that in the unique case of Isaiah 7:14 there are multiple external pressures imposing upon his exegesis of this particular Old Testament passage, including: Jewish, Greek, Marcionite, and Christian pressures. Then, I will turn to 1Apol. 33 to demonstrate how Justin's exegesis of Isaiah 7:14 accounts for these external pressures, which prompts him to focus upon the particular Lukan terminology of 'Power' rather than 'Spirit'. Finally, I will suggest that Justin's christological exegesis of Isaiah 7:14, in response to the various pressures of his day, brackets out his consideration of the function of the Spirit in the incarnation. This exegetical move might seemingly expose him to binitarian allegations, but in reality the functions of the Spirit are clearly developed to the point that his christological reading of Isaiah 7:14 and Luke 1:35 resists confusing them in $1 \mathrm{Apol}$. 33 and focuses exclusively on the way the passage is fulfilled in Christ. This christological attention to Isaiah 7:14 reflects the way an ear- 
ly Christian might reason through the textual and theological complexities of scriptural interpretation within his polemical contexts.

\section{The Hermeneutical Context of Justin's Reading of Isaiah 7:14}

As Justin sets about the task of the exegesis of Isaiah $7: 14$, he has at least four different external pressures imposing upon his interpretation. In Justin's work, this text appears among his debates with his Jewish interlocutor Trypho, Marcion, and even Greco-Roman mythological readings. At the same time, he also interprets this passage within his own understanding of the apostolic faith. There is a distinctiveness to the way he handles each of these competing readings, which ultimately turns his focus to the incarnation of the Logos.

First, Justin reads Isaiah 7:14 in a way that distinguishes his christological reflection from competing Jewish interpretations (Hartog 2017: 114118). The Jewish-Christian dispute over the reading of Isaiah 7:14 is longstanding. Heine notes that besides perhaps the cross, the Jews were most offended by the virgin birth (Heine 2007: 116). Justin's own translation demonstrates the Jewish preference for the term 'young woman' (almah) over and against the Septuagint and Matthean reading of 'virgin'

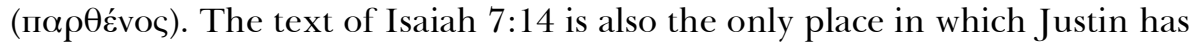
Trypho object to his quotation of the Septuagint, which suggests the importance of this text in their discourse. But while Justin argues for the authority of the Septuagint reading, the crux of his argument is refuting Trypho's interpretation that Isaiah 7:14 is fulfilled in Hezekiah (see Dial. 43.5-6, 66.2-3, 68.6, 71.1-3, 84.1; Heine, 207: 117; Skarsaune 1987: 200201). In his defense of Isaiah 7:14, Justin provides a three-tiered explanation including: arguing for the authority of the LXX reading, arguing the 'sign' God states he would give could not be birth by means of sexual intercourse, and appealing to the fulfillment of Isaiah 8:4 in Christ.

Skarsaune also notes that Justin uses a different source for his discussion on the virgin birth in the Dialogue than in 1Apol. 33. The source behind the Dialogue, the 'anti-Hezekiah' source, was much more polemical. Concerning the nature of the source, Skarsaune concludes, 'Justin's argument on the virgin birth in Dial. $77 \mathrm{ff}$ derives from a source in which Jesus the Son of God, the second Adam, is contrasted with Hezekiah and Solomon. They were only human, while the Son of God is divine and has power over Satan

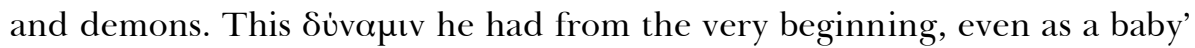
(Skarsaune 1987: 203). This attention to the power of God will be essential to his reading of Luke 1:35 in 1Apol. 33 where he will downplay the language of the Spirit and focus on the language of power.

The case Justin makes for his reading of Isaiah 7:14-16, as Heine observes, depends upon Isaiah 8:4 (Heine 2007: 117). This is most apparent 
in Dial. 66.2-3, where Justin inserts Isaiah 8:4 into a citation of Isaiah 7:1416, saying:

Behold the virgin will conceive and bear a son, and they will call his name Emmanuel. He will eat butter and honey. Before he either knows or prefers evil he will choose the good. For before the child knows evil or good he rejects evil to choose the good [Isaiah 7:14-16a]. For before the child knows how to say father or mother he will receive the power of Damascus and the spoils of Samaria before the king of Assyria [Isaiah 8:4]. And the land will be deserted [Isaiah 7:16b].

This language is closely related to similar language in Dial. 43.5-6, and the interpolation of the allusion to Isaiah 8:4 must be the work of a Christian reading of these texts. The linguistic connections between Isaiah 7:14 and Isaiah 8:4 are apparent; both depend upon the phrase 'For before the child

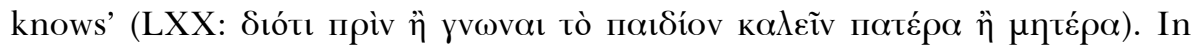
this case, the interpolated passage of Isaiah 8:4 demands that the child born in Isaiah 7:14 has the ability, or the 'power', to conquer Damascus, Samaria, and the King of Assyria. Hezekiah, Justin argues, never waged war against Damascus or Samaria, but the magi, who come from Arabia to worship the child, reveal how Christ conquered these regions. Justin interprets the language of Isaiah 8:4, 'the power of Damascus' and 'the spoils of Samaria,' as the evil powers who inhabited these regions (Dial. 77.3-4, 78.9-10). The magi symbolize that Christ overcame these powers at his birth, thereby simultaneously fulfilling Isaiah 7:14 and Isaiah 8:4. In Justin's thinking, for Christ to fulfill Isaiah 7:14 and Isaiah 8:4 he must come in power and possess this power 'from the very beginning, even as a baby' (Skarsaune 1987: 203, see also Dial. 77.2.). Justin certainly claims that the 'Holy Spirit' announced this prophecy (1Apol. 33.1), yet the fulfillment is tied exclusively to the work of Christ, so that Justin's concern is demonstrating that Christ fulfilled Isaiah 7:14 and Isaiah 8:14 and came with 'power'. This suggests that Justin does have a clearer pneumatology that is tied to the inspiration of prophecy, while the fulfillment of prophecy is directed to the person of Christ. This exegetical orientation will be important when analyzing $1 \mathrm{Apol}$. 33 and evaluating his reading of Luke 1:35 in light of his reading of Isaiah $7: 14$.

Second, Justin distinguishes his understanding of the virgin birth from Greco-Roman mythology. On several occasions, he mentions the accusation that Christian renderings of the virgin birth plagiarized the conception of Perseus though Zeus and Danaë. Justin has Trypho make this indictment in Dial. 67.2, saying:

But in the so-called Greek myths it speaks of how Perseus was born of Danaë, while she was a virgin, when the one whom they call Zeus descended upon her in 
the form of a golden shower. You [Christians] should be ashamed of yourselves to repeat similar stories like these... (Dial. 67.2).

As Trypho implies, when Zeus transforms into a 'golden shower' and descends upon the virgin Danaë, this description is noticeably similar to the account of the Holy Spirit and Power of the Most High overshadowing the virgin in Luke 1:35. Justin alludes to the same argument in 1Apol. 33, but here he underlines the sexual nature of the conception, noting: 'Zeus came upon the women through lust' (1Apol. 33.2 see also 1Apol. 54). Even the language Justin uses in 1Apol. 33.3 to describe how Zeus 'came upon' ( $\dot{\varepsilon} \lambda \eta \lambda v \theta \dot{\varepsilon} v \alpha \iota \dot{\varepsilon} \Pi i)$ the women is similar to the language found in Luke 1:35

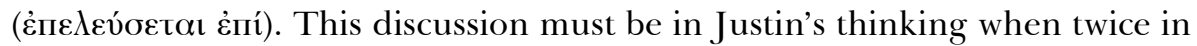
1Apol. 33 Justin explicitly rejects the notion of 'sexual intercourse' in the virgin birth (1Apol. 33.4, 33.6). Therefore, while Justin must demonstrate how Christ came with power to fulfill Isaiah 7:14 and Isaiah 8:4, he must interpret Isaiah 7:14 in a way that is not mythological or suggests interpersonal conception through intercourse. Once again, the focus on the Power rather than on some personal interaction through the Spirit would answer any metaphysical fears about the conception.

The third pressure comes by way of Marcion. We know from Tertullian that Marcion refutes the christological interpretation of Isaiah 7:14, based upon Isaiah 8:4; the very same texts Justin uses to refute Trypho. Citing Marcion, Tertullian writes,

For, in the first place, you [Marcion] say, Isaiah's Christ will have to be named Emmanuel, and afterwards take up the power of Damascus and the spoils of Samaria against the king of Assyria. Again, that one who has come was neither born under such a name, nor ever engaged in any military activity (Adv. Marc. 3.12.1; see also Tertullian Adv. Jud. 9.1 and Harnack 1990: 55).

As we have already seen, Justin argues Hezekiah never took up arms as Isaiah 8:4 proclaims the Messiah would do, but here Marcion makes the same argument against Christ. In fact, Harnack determines that the combination of Isaiah 7:14 and Isaiah 8:4 must be decisive texts in his lost Antitheses (Marcion 1990: 59-60). Although Justin does not mention Marcion's writings, he is clearly aware of the extent of his influence (1Apol. 26.5; 58.1-2; Dial. 56.). We also know that prior to the Apologies, Justin composed his lost Syntagma refuting various Christian heresies and, assuming that these are not the same work, Irenaeus also reports of another work Justin produced against Marcion. This assumes, of course, that the work Irenaeus mentions is the same one Justin mentions in 1Apol. 27.6 (Haer. 4.6.2). But either way, Irenaeus is still witness to the fact that Justin has composed a work specifically refuting Marcion. If the combination of Isaiah 7:14 and 8:4 is as im- 
portant to Marcion as Harnack surmises, than its likely that Justin's use of these texts derives from his refutation of Marcion, and Justin then uses this argument against Trypho. Skarsaune even suggests the arguments of Dial. 43, 66, and 77 are all derived from a Christian source, which conflates Isaiah 7:14 and Isaiah 8:4. Determining the exact relationship between the conflation of these texts in Justin's source, Justin's arguments, and Marcion's works remains a problematic issue. But whatever the case, clearly Justin's exegetical logic is focused on the fulfilment of the 'power' of Christ that is connected to the virgin birth.

Finally, Justin reads scripture within his own Christian tradition, which is evidenced in his descriptions of various creedal formulas. In his summary of Justin's exegetical perspective, David Aune writes, 'The chief factor which determined the results of Justin's exegesis of the Old Testament was that body of Christian tradition which he inherited from his Christian predecessors and which he maintained virtually without alteration' (Aune 1966: 179). In other words, Justin's tradition constructively shaped his exegesis and his response to these distinctive external exegetical pressures. Skarsaune confirms this assessment, noting that the basis for Justin's selfunderstanding as an exegete is 'handing on a received tradition' (Skarsaune 1987: 11). The essence of this tradition, as Aune goes on to say, is a deeply christological or christo-centric interpretation. In the case of 1Apol. 33, Justin cites the fulfillment report of Luke 1:31-32/Matthew 1:20-21 as confirmation of the fulfillment of Isaiah 7:14. This fulfillment report mentions the

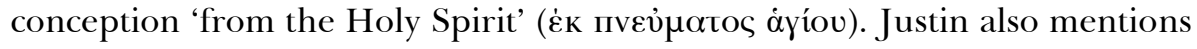
the same language of Matthew 1:20 in the context of his arguments against Trypho in Dial.78.3. Thus, it stands to reason from Justin's own citation that the virgin birth, in some sense, involves the Holy Spirit since the title is mentioned in the fulfillment report?

Given these external pressures, the complex situation of Isaiah 7:14 and the virgin birth begins to take shape. Through Jewish and Marcionite exegesis, Greek mythology, and his received tradition, Justin is placed in a rather complicated exegetical situation. Against Jewish exegetes and Marcion, he must demonstrate how the birth of Christ concurrently fulfills both the reference to the virgin birth in Isaiah 7:14 and the child coming with power in Isaiah 8:4. Justin must also explain how the Lukan account of Christ's birth does not involve sexual intercourse and is not mythological when it describes the metaphysical aspects of the incarnation. At the same time, he must faithfully pass on the Christian tradition he received and remain faithful to the apostolic witness. With all these points in mind, it is now possible to assess Justin's reading of Isaiah 7:14 and Luke 1:35 in 1Apol. 33. 


\section{Reassessing 1Apol. 33: the Spirit, the Power, and the Logos}

This summary of Justin's exegetical milieu brings us now to the crucial passage of 1Apol. 33. All the external pressures mentioned earlier are explicitly or implicitly present in this section. The entire section of 1 Apol. 33 is framed by a three-fold scheme that Skarsaune identified, including: the citation of a prophecy, the exposition of the prophecy, and the citation of a fulfillment report (Skarsaune 1987: 145). Following this scheme, he cites the prophecy of Isaiah 7:14 in the opening lines of 1 Apol. 33. He then provides the "exposition' of this verse with particular attention given to the phrase, 'behold a virgin will conceive' (1Apol. 33.4). He argues that this phrase actually means

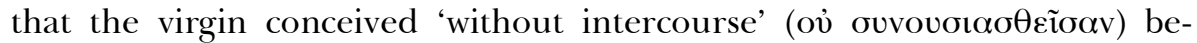
cause the virgin conceived and remained a virgin. Justin's emphasis on the 'power' of God and the incarnation is evident within this opening portion of the section. He contends that this exposition distinguishes Christ from Zeus' progeny, because the virgin conceived not by intercourse, but by the "power of God' (Súvauıs $\theta \varepsilon o \tilde{)}$ ) (1Apol. 33.4; see also Dial. 78.9, Heine 2007: 117 18). This claim also distinguishes the birth of Christ from someone who was born of natural means, such as Hezekiah (Dial. 43.7-8). Furthermore, in his exegesis, Justin interprets Isaiah 7:14 with terminology borrowed from Luke 1:35, saying: 'but the power of God having come upon the virgin overshadowed her, and caused her to conceive while still a virgin'. In this context, as de Aldama notes, Justin excludes any mention of the Spirit and concentrates exclusively upon the 'power of God' in Luke 1:35. In light of his exegetical pressures, this move makes sense because the fulfillment of Isaiah 7:14 and 8:4 depends upon Christ coming in power, not, in Justin's thinking, the relationship between the Son and the Spirit (de Aldama 1970: 145). It is not that Justin confuses the Logos and the Spirit, but in this case he prefers to interpret the passage in light of Christ. The discussion of the Spirit is simply not part of his exegetical agenda.

Interestingly enough, it is actually rare for Justin to mention any passage

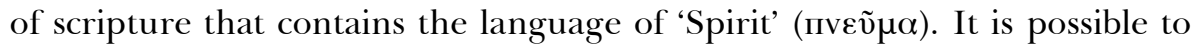
count on two hands the number of texts Justin cites that even mention the title 'Spirit': Luke 1:31-32/Matthew 1:20-21 in 1Apol. 33; Genesis 1:2 in 1Apol. 60, 64; Matthew 3:11-12 in Dial. 49; Isaiah 42:5-13 in Dial. 65; Matthew 1:20 in Dial. 78; Isaiah 11:1-3 in Dial. 87; Joel 2:28-29 in Dial. 87; Luke 1:35 in Dial. 100; and Isaiah 42:1-4 in Dial. 123. Other than the Spirit hovering over the water in Genesis 1:2 in 1Apol. 60 and 64, all of these texts address either Christ's virgin birth or baptism. Based on the paucity of evidence, there is no clear indication that Justin is concerned with identifying the function of the Spirit in scripture; though, as mentioned above, he does hold fast to the prophetic function of the Spirit. Instead, Justin's exegesis is 
concerned with how these few Spirit-inspired prophetic texts or fulfillment texts, which happen to mention the Spirit, portray the work of Christ.

Justin follows his citation and exposition of Isaiah 7:14 with a 'fulfillment report' in a conflation of Luke 1:31-32/Matthew 1:20-21, saying: 'Behold, you will conceive in the womb of the Holy Spirit and will bear a son, and He will be called Son of the Highest, and you will call His name Jesus, for he will save His people from their sins.' Although it is not part of the citation, Justin alludes to Luke 1:30 in a short preface to this citation, and it does not appear to be part of the testimony source. But the presence of the allusion to Luke 1:30 implies that Justin was readily aware of the context of the fulfillment report of Luke 1:31-32/Matthew 1:20-21. It is obvious that he did not assemble this fulfillment passage ad hoc, as demonstrated by the close parallels with the Protevangelium Jacobi 11:3 (Skarsuane 1987: 145). It also appears that the testimony source is drawn to the verbal connections between Isaiah 7:14 and Luke 1:31-32/Matthew 1:20-21, including: 'to bear children', 'virgin', 'womb', and 'Son' (noticeably not the language of 'Spirit').

The fulfillment passage states that Christ would be conceived in the

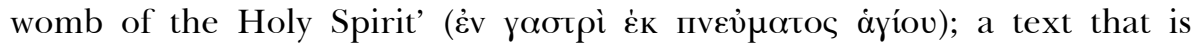
drawn from Matthew 1:20 and inserted into Luke 1:31a (1Apol. 33.5). As Skarsaune notes, the thrust of this fulfillment report is located in the 'Son of God' concept rather than the Spirit. Justin immediately follows this fulfillment passage with his own commentary, again borrowing from Luke 1:35. Skarsuane suggests this portion of $1 \mathrm{Apol}$. 33.6ff reads 'like an added comment', which is important since he is commenting on the fulfillment report he quotes (Skarsuane 1987: 273). Thus, following the fulfillment report, Justin writes:

It is established that the Spirit and the Power from God are to be understood as none other than the Word, who is also the First-begotten of God, as Moses the previously mentioned prophet testified; and when this one came upon the virgin and overshadowed her, caused her to conceive not by intercourse, but by power (1Apol. 33.6).

Therefore, Justin coordinates the language of the Spirit, Power, and Logos, but in the second half of the citation, Justin retreats from the mention of the Spirit to focus on the 'Power'. This is the same tendency reflected in his earlier citation of Luke 1:35. It is not that Justin confuses the function of the Spirit and the Logos, but simply that his only concern is to emphasize the 'power' that came upon the woman. The reference to the Spirit in the Lukan text is simply not part of his exegetical perspective, nor is it necessary for his apologetic.

A significant textual issue in 1 Apol. 33.6 is the question of the pronoun тои̃тo in the phrase 'when this one (тог̃⿰о) came upon the virgin', which ini- 
tiates this second allusion to Luke 1:35. Noting that it is neuter singular, the

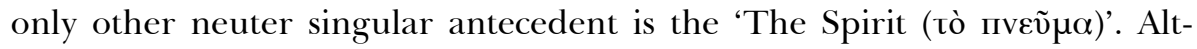
hough it is possible, it is unlikely that the neuter would refer to the feminine

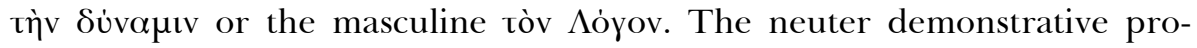
nouns may also have a more conceptual sense, such as 'the former'. Dan Wallace notes twenty-two instances of kaì toṽto in the New Testament, of which fourteen to fifteen have conceptual referents, four are adverbial, and three have gender-specific referents. None use the neuter to refer to a different gender (Wallace 1996: 334-335). A survey of Liddell-Scott suggests a similar trend (Liddell-Scott 1996: 1275-1276). Therefore, the neuter pronoun toṽto, in all likelihood, refers back to the 'Spirit' in the opening of 1Apol. 33.6. This means that Justin reduces the title 'Holy Spirit' in Luke 1:35 to 'Spirit' in the opening lines of $1 \mathrm{Apol}$. 33.6, and then to the simple demonstrative pronoun (тои̃т). Martin suggests that in this instance Justin

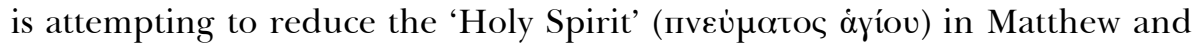

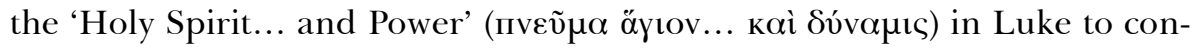
centrate solely on the 'Power' (Martin 1971: 185-186). Again this makes sense, given the external pressures he faced. When he downplays the language of 'Spirit' and emphasizes the language of 'Power', he states the vir-

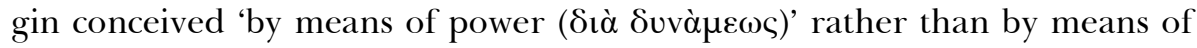
'intercourse (ouvousias)'.

This brings Justin full circle to his earlier point, 'a virgin shall conceive without intercourse' (1Apol. 33.4). Above all, Justin wants to argue that Isaiah 7:14 demonstrates that the virgin conceived though 'Power' not intercourse (Skarsaune 1987: 200). Skarsaune states that the same focus is found in the Dialogue, 'The point Justin wanted to make by these testimonies is formulated with great uniformity: The Messiah should not be born of human seed/human origin' (Skarsaune 1987: 200). In his only other citation of Luke 1:35 in Dial. 100.5, Justin uses the language of 'Spirit of the Lord', which is another move away from interpreting the language in light of the Spirit. In addition, in the previous section of 1Apol. 32, Justin alludes to the citation of Genesis 49:10-11 to identify the Logos with the first-born Power from God, and that it is this 'Power' who is involved in the conception of the virgin. Elsewhere, in Dial. 84, Justin mentions that in scripture the barren are often able to conceive through the power of God. He cites Sarah in Genesis 21.2, Hannah in 1 Samuel 1:20, and Elizabeth in Luke 1:57.

All of this discussion points to the simple fact that Justin does not confuse the Spirit and the Logos in his allusion to Luke 1:35 in 1Apol. 33. Given his exegetical pressures, the 'Spirit' is quite simply not part of his exegetical perspective, and instead he is much more concerned with the identity of the 'Power' of God. He downplays any discussion of the role of the Spirit even though the language of 'Spirit' appears in the passage. This view amounts 
to a theological perspective termed the 'self-incarnation of the Word' (de Aldama 1970: 146; see also Bucur 2008: 196. Granados 2005: 149-152; Simonetti 1972: 213; Oeyen 1972: 215-221). This is an exclusively christological rendering of the incarnation that Justin feels distances him from the variety of external pressures. This does not mean that Justin denies the activity of the Spirit in the incarnation, he simply does not discuss it given his exegetical context. Thus, this move was part of broader exegetical discussions as Justin reasons through the complexities of christological readings of the Old Testament. Though Justin may be charged with ignoring the Spirit that is obviously mentioned in the allusion to Luke 1:35, he focuses exclusively on the power of God in a way that addresses the pressing needs of his exegetical context. It cannot be said that he denies the deity of the Spirit or that he confuses the Spirit and the Logos in 1Apol. 33, but that he simply does not make the identification of the Spirit in Luke 1:35 part of his exegetical treatment of the fulfilment of Isaiah 7:14.

\section{Conclusion}

In conclusion, it seems that Justin arrives at this enigmatic language in 1Apol. 33, 'It is established that the Spirit and the Power of God are to be understood as none other than the Logos', by way of attempting to validate a christological proof from prophecy in Isaiah 7:14, while borrowing the language of Luke 1:35. Stressing the 'power' in Luke 1:35 allows him to note that Christ came with power, which distinguishes his reading from other competing readings. The emphasis on power separates his interpretation from any kind of personal conception through sexual intercourse, which distances him from Greek mythology. His attention to the 'Power' in Luke 1:35, furthermore, allows for the concurrent fulfillment of Isaiah 7:14 and Isaiah 8:4, so that the one who was born of the virgin also came with the power to overtake the power of Damascus and the spoils of Samaria. This reading distinguishes Justin from Marcionite charges and from the Jewish interpretation that focuses on the figure of Hezekiah. Thus, in the midst of Justin's external pressures, his emphasis on the christological interpretation of Isaiah 7:14 curtails any consideration of the Spirit, even in the context of his own testimony sources.

This study demonstrates that Justin does not confuse the Logos and the Spirit, and that he is not binitarian in his theological reasoning in 1 Apol. 33. Justin has a place for the function of the Spirit in his theology, but when he reasons through the fulfillment of Isaiah 7:14 his concern is attentive to the fulfillment of Christ coming in power. This study helps explain why Justin provides certain exegetical conclusions that have elicited binitarian accusations, because his ultimate concern in 1Apol. 33 is to demonstrate how the Old Testament text of Isaiah 7:14 is fulfilled in Christ, not the Spirit. From 
this study, it might even be suggested that the distinctions between the Logos and the Spirit are actually rather defined in his hermeneutical logic. Even when a fulfillment report uses the title 'Spirit', this does not sway his theological reasoning within his apologetic claim as he aims to demonstrate Christ from the Old Testament.

\section{Bibliography}

Aldama JA de (1970) El Espíritu Santo y el Verbo en la exégesis de Lc 1:35. In María en la patrística de los siglos I y II (Biblioteca de Autores Cristianos 300). Madrid: La Editorial Católica, pp. 140-166.

Aune D (1966) Justin Martyr's Use of the Old Testament. Bulletin of the Evangelical Theological Society 9(4): 179-197.

Barnard LW (1967) Justin Martyr: His Life and Thought. Cambridge: University Press.

Barnes MR (2001) Early Christian Binitarianism: the Father and the Holy Spirit. Paper presented at the 2001 North American Patristic Society Annual Conference, Chicago, IL.

Behr J (2001) Way to Nicaea. Crestwood, NY: St. Vladimir's Seminary Press.

Briggman A (2009) Measuring Justin's Approach to the Spirit: Trinitarian Conviction and Binitarian Orientation. Vigiliae Christianae 63(2): 107137.

Bucur BG (2008) The Angelic Spirit in Early Christology: Justin, the Martyr and Philosopher. Journal of Religion 88(2): 190-208.

Edwards MJ (1995) The Word of God and the Logos. Journal of Early Christian Studies 3(3): 261-280.

Evans E (1972) Tertullian: Adversus Marcionem. Oxford: Oxford University Press.

Goodenough E (1968) The Theology of Justin Martyr. Amsterdam: Philo Press.

Granados J (2005) Los Misterios de la Vida de Cristo en Justino Martir. Roma: Editrice Pontificia Universita Gregoriana.

Harnack A von (1990) Marcion: The Gospel of the Alien God. Durham, NC: Labyrinth Press.

Hartog P (2017) The Good News in Old Texts? The 'Gospel' and the 'Archives' in Ign. Phld. 8.2. Studia Patristica 93(*): 105-121.

Heine RE (2007) Reading the Old Testament with the Ancient Church. Grand Rapids, MI: Baker.

Justin Martyr (1994) Apologies: Iustini martyris apologiae pro christianis, Markovich M (ed), (Patristische Texte Studien 38). Berlin: De Gruyter.

Justin Martyr (1997) Dialogue with Trypho the Jew: Iustini martyris dialogues cum Trophone, Markovich M (ed) (Patristische Texte Studien 47). Berlin: De Gruyter. 
Liddell HG, Scott R, and Jones HS (1996) Greek-English Lexicon. Oxford: Clarendon Press.

Martín JP (1971) El Espíritu Santo en los origenes del Christianismo: Estudio sobre I Clemente, Ignacio, II Clemente y Justino Martir. Zürich: PAS Verlag.

Oeyen C (1972) Die Lehre der göttlichen Kräfte bei Justin. Studia Patristica 11(2): 215-221.

Osborn E (1973) Justin Martyr. Tübingen: Mohr Siebeck.

Shotwell WA (1965) The Biblical Exegesis of Justin Martyr. London: SPCK.

Simonetti M (1972) Note di cristologia pneumatica. Augustinianum 12(2): 201-232.

Skarsaune O (1987) The Proof from Prophecy: A Study in Justin Martyr's Prooftext Tradition: Text-type, Provenance, Theological Profile. Leiden: Brill.

Stanton G (2004) The Spirit in the Writings of Justin Martyr. In The Holy Spirit and Christian Origins: Essays in Honor of James D. G. Dunn, Stanton GN, Longenecker B, and Barton SC (eds). Grand Rapids, MI: Eerdmans, pp. 321-334.

Tränkle H (1964) Tertulliani Adversus Judaeos mit Einleitung und kritischem Kommentar. Wiesbaden: Franz Steiner Verlag.

Vigne D (2000) 'Pneuma Prophetikon', Justin et le Prophetisme. In Vannier M-A (ed) Anthropos laïkos Mélanges Alexandre Faivre à l'occasion de ses 30 ans d'enseignement. Fribourg: Éditions Universitaires, pp. 335-347.

Wallace D (1996) Greek Grammar Beyond the Basics. Grand Rapids, MI: Zondervan. 